\title{
Effect of air drying on quality characteristics and mass transfer kinetics of osmotically dehydrated sea buckthorn by stevia
}

\author{
Lentzou, D., Templalexis, Ch. and *Xanthopoulos, G. \\ Department of Natural Resources Management and Agricultural Engineering, Faculty of School of \\ Environment and Agricultural Engineering, Agricultural University of Athens, 75 Iera Odos Str., 11855, \\ Athens, Greece
}

\begin{abstract}
Article history:
Received: 19 January 2020

Received in revised form: 1

March 2020

Accepted: 3 March 2020

Available Online: 27 March 2020
\end{abstract}

\section{Keywords:}

Sea buckthorn,

Stevia,

Osmotic dehydration,

Air-drying

\section{DOI:}

https://doi.org/10.26656/fr.2017.4(4).031

\begin{abstract}
Sea buckthorn is ranked among the most significant super foods worldwide. Its fruits and leaves are used as fresh or dried in food, pharmaceutical and cosmetic industry. As super food any pre-treatment should sustain this property and hence this research was focused on osmotic dehydration of sea buckthorn by stevia also a super food. Therefore, water loss, sugar gain, acidity, ascorbic acid and water diffusivity were evaluated during osmotic dehydration of sea buckthorn by two stevia solutions, $15^{\circ}$ and $30^{\circ}$ Brix and following were air-dried at $50^{\circ} \mathrm{C}$ by comparing the effect of steam blanching per case. Steam blanched samples exhibited increased water loss at the end of the process, $55 \%$ at $30^{\circ}$ Brix and $48 \%$ at $15^{\circ}$ Brix, compared to untreated samples where losses were $43 \%\left(30^{\circ} \mathrm{Brix}\right)$ and $28 \%$ $\left(15^{\circ}\right.$ Brix) respectively. Ascorbic acid was significantly reduced, exceeding $50 \%$ in steam blanched samples and $23 \%$ in untreated samples. Steam blanched samples dehydrated at $15^{\circ}$ Brix exhibited $82 \%$ dry matter increase and only $39 \%$ the untreated samples. Similarly, samples dehydrated at $30^{\circ}$ Brix exhibited $84 \%$ dry matter increase and $53 \%$ when no steam blanching was applied. Solid gain was seven times less compared to water loss which is attributed to high molecular weight of steviol glycoside. The osmotic dehydration and airdrying curves were described effectively by Peleg and Fick models, and Logarithmic and Fick models respectively, having in all cases $\mathrm{R}_{\text {adj }}^{2}>99 \%$ and $\mathrm{SEE}<0.2$. The water diffusivity of steam blanched samples was $3.2-5.57 \times 10^{-11} \mathrm{~m}^{2} / \mathrm{s}$ for water loss and 1.27$2.03 \times 10^{-11} \mathrm{~m}^{2} / \mathrm{s}$ for solid gain at $30^{\circ}$ Brix and $2.12-4.27 \times 10^{-11} \mathrm{~m}^{2} / \mathrm{s}$ and $0.91-1.98 \times 10^{-11} \mathrm{~m}^{2} / \mathrm{s}$ at $15^{\circ}$ Brix. Finally, the water diffusivity of steam blanched samples during air-drying was $2.11-2.29 \times 10^{-11} \mathrm{~m}^{2} / \mathrm{s}$ and $1.56-1.66 \times 10^{-11} \mathrm{~m}^{2} / \mathrm{s}$ in the case of untreated samples.
\end{abstract}

\section{Introduction}

Sea buckthorn (Hippophaes rhamonides $L$ ) is among the most important superfoods and is used for its fruits as well its leaves. Its fruits are consumed either as fresh or dried mainly in the pharmaceutical and cosmetic industry. Sea buckthorn has many nutritional benefits as it has been reported to contain more than 190 essential compounds in seeds, pulp, fruit and juice, such as vitamins $\mathrm{A}, \mathrm{K}, \mathrm{C}, \mathrm{B} 1, \mathrm{~B} 2$ and $\mathrm{E}$, fatty acids, lipids, organic acids, amino acids, carbohydrates, folic acid, tocopherols, flavonoids, phenols, terpenes and tannins which have beneficial effects on health (Bal et al., 2011).

The composition of sea buckthorn juice varies according to cultivar, growing conditions, harvest time, ripeness and processing technology. Has been found to contain high quantities of ascorbic acid ranging between
28 to $2,500 \mathrm{mg} / 100 \mathrm{~g}$. The $\mathrm{pH}$ of sea buckthorn juice ranges from 2.7 to 3.1 which do not favour ascorbate oxidase activation and therefore ascorbic acid is largely retained during juice processing. The soluble solids content ranges from 7.0 up to $22.7^{\circ}$ Brix. The sea buckthorn juice is characterized by high quantities of various organic acids so its acidity ranges from 3.5 to $7.3 \%$ (Zeb, 2004).

Stevia is a natural sweetener used in food and beverage industry as a sugar substitute. A part of stevia is 15 to 30 times sweeter than a part of sucrose (Savita et al., 2004). Stevia plant (Stevia rebaudiana Bertoni) belongs to the family of Compositae or Asteraceae, subfamily of Eupatorieae. Have been identified 280 species to belong at stevia genus but only Stevia rebaudiana has intense sweetening power (LemusMondaca et al., 2012). The stevia plant is a good source 
of carbohydrates, proteins, fibres, metals, essential and non-amino acids. The physical and chemical characteristics of the extracted stevioside, as well as its thermal and acid stability along with its superior sensorial characteristics, have spread its use in food and beverage industry (Abou-Arab et al., 2010). The objectives of this study were (i) to conduct osmotic dehydration of sea buckthorn maintaining its superior nutritional value adopting an equal nutritional value hypertonic medium, this of stevia, (ii) to evaluate the water loss, sugar gain, acidity, ascorbic acid concentration and water diffusivity of sea buckthorn (var. Chuyskaya) initially osmotically dehydrated in two stevia solutions, $15^{\circ}$ Brix and $30^{\circ}$ Brix and then air-dried at $50^{\circ} \mathrm{C}$ by comparing the effect of steam blanching application to each tested case.

\section{Materials and methods}

Sea buckthorn fruits (var. Chuyskaya) were supplied from Agricultural Co-operative of Karditsa (Northern Greece). The fruits were transported to the laboratory where defective fruits (injured, overripe, etc) were discarded. Measurements of weight, acidity, soluble solids and ascorbic acid were carried out in two groups of 50 fruits each. In group A, the 50 fruits weighed 38.15 $\mathrm{g}$ and in group $\mathrm{B}, 35.77 \mathrm{~g}$; the total soluble solids was $9.1 \%$ and $8.2 \%$ respectively; for group $\mathrm{A}$ the malic acid was $0.34 \%$, the citric acid, $0.54 \%$ and the ascorbic acid, $487.2 \mathrm{ppm}$ while for group B the malic acid was $0.31 \%$, the citric acid, $0.51 \%$ and the ascorbic acid, $490.9 \mathrm{ppm}$. The average initial moisture content was $9.83 \pm 0.2 \mathrm{~kg}_{\mathrm{w}} /$ $\mathrm{kg}_{\mathrm{dm}}$ and was estimated gravimetrically using a vacuum oven (VD 53, Binder, Germany) at $70^{\circ} \mathrm{C}$ for $24 \mathrm{hrs}$ (AOAC, 1997).

Four experimental series were osmotically dehydrated at $40^{\circ} \mathrm{C}$, two in $30^{\circ}$ Brix solutions and two in $15^{\circ}$ Brix solutions, and upon completion of osmosis, the samples were air-dried at $50^{\circ} \mathrm{C}$. The weight ratio of the osmotic solution to fruit sample was $28: 1\left(30^{\circ}\right.$ Brix $)$ and 24:1 (15 ${ }^{\circ}$ Brix) based on Yadav and Singh (2014) review. Since stevia is $15-30$ times sweeter than sucrose, a higher dilution ratio was adopted than the one is normally used in sucrose solutions (Yadav and Singh, 2014). The difference between the two experimental series per stevia solution was based on the application or not of steam blanching for 3 mins. In each experimental series $25 \mathrm{~g}$ per sample were placed in small perforated pouches and immersed in two stevia solutions. Six replicates were used per experimental series. The samples were osmotically dehydrated for $6 \mathrm{hrs}$ in $750 \mathrm{~mL}$ beakers containing the stevia solutions and the samples were weighed in hourly intervals. Upon removal from the osmotic solutions, the samples were drained and the excess of the stevia solution removed with absorbent paper. The solid content of the osmotically dehydrated fruits was determined gravimetrically using a vacuum oven (VD 53, Binder, Germany) at $70^{\circ} \mathrm{C}$ for $24 \mathrm{hrs}$ (AOAC, 1997). Measurements regarding total soluble solids, acidity and ascorbic acid were conducted in two replicates as follows. The remaining samples were airdried at $50^{\circ} \mathrm{C}$ until steady weight was achieved. Upon drying, hourly weighing of the samples was carried out. At the end of the air-drying, the acidity, the total soluble solids and the ascorbic acid of the dried samples were evaluated. The dried samples were pulped, diluted with $10 \mathrm{~mL}$ of deionised water and filtered so the remaining juice to be used for measurements of the total soluble solids, acidity and ascorbic acid. The geometric mean diameter in terms of Feret diameter was estimated by image analysis employing Image $1.46 \mathrm{r}$ image analysis software (Research Services Branch, NIMH, Bethesda, USA). For this purpose, twenty randomly selected sea buckthorn berries were photographed by a digital camera Konica Minolta Dimage Z2 (4.0 Mpixel) and analysed so the mean diameter was measured as $0.707 \mathrm{~cm}$.

\subsection{Theoretical aspects, water and solute diffusivity estimation}

The water adsorption/desorption during osmotic dehydration has been described by theoretical or semitheoretical models. Also, a number of empirical models have been used to solve the diffusion problem. The most employed empirical model in literature (Park et al., 2002; Azoubel and Murr, 2004), for water adsorption/ desorption in foods during osmosis belongs to Peleg (1988),

$$
M C_{t}=M C_{o} \pm \frac{t}{K_{1}+K_{2} t}
$$

where $M C_{t}$ is the moisture content $\left(\mathrm{kg}_{\mathrm{w}} / \mathrm{kg}_{\mathrm{dm}}\right)$ for immersion time $\mathrm{t}(\mathrm{min}), M C_{o}$ is the initial moisture content $\left(\mathrm{kg}_{\mathrm{w}} / \mathrm{kg}_{\mathrm{dm}}\right), K_{l}$ is the temperature dependent Peleg constant $\left[\mathrm{h} /\left(\mathrm{kg}_{\mathrm{w}} / \mathrm{kg}_{\mathrm{dm}}\right)\right]$ related to dehydration rate at the beginning of the process, $\left(\frac{\mathrm{dMC}_{\mathrm{C}}}{\mathrm{dt}}= \pm \frac{1}{\mathrm{~K}_{1}}\right)$ and $K_{2}$ is Peleg constant $\left(\mathrm{kg}_{\mathrm{w}} / \mathrm{kg}_{\mathrm{db}}\right)^{-1}$ determined by the moisture concentration in $\left(\mathrm{MC}_{0}=\mathrm{MC}_{0} \pm \frac{1}{K_{2}}, t \rightarrow \infty\right)$ equilibrium The \pm sign in Equation 1 corresponds to adsorption $(+)$ and desorption (-) respectively.

The air-drying curves have been simulated by various semi-empirical models (Henderson, 1974; Whith et al., 1978; Wang and Singh, 1978; Sharaf-Eldeen et al., 1980; Zhang and Litchfield, 1991; Diamente and Munro, 1993; Yağc1oğlu et al., 1999; Karathanos, 1999; Yaldýz and Ertekýn, 2001; Pakowski and Mujumdar, 2006) based on the analytical solution of Fick equation (cf. in Table 1). In many cited studies the Logarithmic model has been found to simulate efficiently experimental air- 
drying curves (Xanthopoulos, Lambrinos and Manolopoulou, 2007; Xanthopoulos, Oikonomou and Lambrinos, 2007; Xanthopoulos et al., 2010).

Considering sea buckthorn fruit as a sphere of uniform initial water $\left(\mathrm{MC}_{\mathrm{o}}\right)$ and solids content, the analytical solution of Fick equation for constant process conditions is given by Crank (1975).

$$
M R=\frac{M C_{t}-M C_{e}}{M C_{o}-M C_{e}}=\frac{6}{\pi^{2}} \cdot \sum_{n=1}^{\infty} \frac{1}{n^{2}} \cdot \exp \left(-n^{2} \cdot \frac{\pi^{2} \cdot D \cdot t}{r_{e}^{2}}\right)
$$

Where $n$ is the number of terms taken in the series, $D$ is the effective diffusivity $\left(\mathrm{m}^{2} / \mathrm{s}\right), t$ is the process time (s) and $r_{e}$ is the mean geometric radius (m).

Considering the first term $(n=1)$ of the series (Equation 2) derives an error over 60\% (Efremov and Kudra, 2005) at the beginning of the process $\left(\mathrm{F}_{\mathrm{o}}=0\right)$. The estimation error drops to $4 \%$ when 15 terms are considered, whereas 58 terms are needed to achieve error close to $1 \%$. Efremov and Kudra (2005) minimized this error by integrating the correction factor $\alpha^{\prime}$ (cf. to Equation 3) without considering many terms.

$$
\mathrm{MR}=\exp \left(-\pi^{2} \cdot \mathrm{F}_{\mathrm{o}}^{\alpha^{\prime}}\right)
$$

Where $F_{o}$ is the Fourier number. For spherical shape, the correction factor $\alpha^{\prime}=0.83$ results in a maximum relative error of $\pm 17 \%$. Equation 3 is solved with respect to $D$ as follows,

$$
\mathrm{D}=\frac{\mathrm{r}_{\mathrm{e}}^{2}}{\pi^{2 / \alpha^{\prime}} \cdot t} \cdot(-\ln \mathrm{MR})^{1 / \alpha^{\prime}}
$$

Mundada et al. (2010) employed the analytical solution of Fick equation to estimate the diffusion coefficient of solid gain, Equation 5,

$$
\text { SGR }=\text { solids gain ratio }=\frac{C_{t}-C_{e}}{C_{o}-C_{e}}=\exp \left(-\pi^{2} \cdot F_{o}^{\alpha^{\prime}}\right)
$$

The geometric mean of the diffusion coefficient was estimated for water loss $\left(\left.D_{W L}\right|_{\text {avg }}\right)$ and solid gain $\left(\left.D_{S G}\right|_{\text {avg }}\right)$ during the osmotic dehydration as well as for water loss
$(D)$ during the air-drying of the sea buckthorn as follows (Lentzou et al., 2019).

\subsection{Osmotic dehydration and hot air-drying}

The osmotic solutions of stevia used in this study

$$
\left.\mathrm{D}_{\mathrm{w}, \mathrm{s}}\right|_{\text {avg }}=\left(\prod_{\mathrm{i}=1}^{\mathrm{n}} \mathrm{D}_{\mathrm{i}}\right)^{\frac{1}{n}}
$$

consisted of $500 \mathrm{~mL}$ deionised water and $209 \mathrm{~g}$ stevia powder, case of $30^{\circ}$ Brix solution, and $91 \mathrm{~g}$ of stevia powder, case of $15^{\circ}$ Brix aqueous solution. Dilution of stevia in the deionised water was carried out by means of a heated magnetic stirrer (RCT basic, IKA-Werke $\mathrm{GmbH}$ \& Co. KG, Germany) whose heating plate was set to $40^{\circ}$ C. To sustain the hypertonic solutions at $40^{\circ} \mathrm{C}$ throughout the osmotic process, the beakers containing the osmotic solutions were placed inside a water bath at $40^{\circ} \mathrm{C}$ and the osmotic solutions in the beakers were agitated in regular intervals.

Weighing of the mass was carried out by an electronic balance (KERN, PCB-440, Japan) having $\pm 0.01 \mathrm{~g}$ accuracy. Based on the previous measurements the water loss (Equation 7) and solid gain (Equation 8) were estimated as follows (Panagiotou et al., 1999),

$$
\begin{aligned}
& W L=\left[\left(M_{o}-m_{o}\right)-\left(M_{t}-m_{t}\right)\right] / M_{o} \\
& S G=\left(m_{t}-m_{o}\right) / m_{0}
\end{aligned}
$$

Where $m_{o}, m_{t}$ are the initial dry matter and the dry matter in any time $(\mathrm{kg}) ; M_{o}, M_{t}$ are the initial mass and the mass in any time $(\mathrm{kg}) ; M C_{o}, M C_{t}$ is the initial moisture content and the moisture content in any time $\left(\mathrm{kg}_{\mathrm{w}} / \mathrm{kg}_{\mathrm{dm}}\right)$. The water loss (Equation 7) express the diffused water $\left(\mathrm{kg}_{\text {water loss }} / \mathrm{kg}_{\text {initial mass of fruit }}\right)$ from the fruit to the osmotic

\begin{tabular}{|c|c|c|}
\hline & Models & Reference \\
\hline Lewis (Newton) & $\mathrm{MR}=\exp (-\mathrm{kt})$ & Pakowski and Mujumdar, (2006) \\
\hline Page & $\mathrm{MR}=\exp \left(-\mathrm{kt}^{\mathrm{n}}\right)$ & Diamente and Munro, (1993) \\
\hline Mod. Page & $\mathrm{MR}=\exp \left[-(\mathrm{kt})^{\mathrm{n}}\right]$ & Whith et al. (1978) \\
\hline Henderson and Pabis & $\mathrm{MR}=\mathrm{aexp}(-\mathrm{kt})$ & Zhang and Litchfield (1991) \\
\hline Logarithmic & $M R=a \exp (-k t)+c$ & Yağcioğlu et al. (1999) \\
\hline Two term & $M R=\operatorname{aexp}\left(-k_{0} t\right)+b \exp \left(-k_{1} t\right)$ & Henderson (1974) \\
\hline Exponential two term & $\mathrm{MR}=\mathrm{a} \exp (-\mathrm{kt})+(1-\mathrm{a}) \exp (-\mathrm{akt})$ & Sharaf-Eldeen et al. (1980) \\
\hline Wang and Singh & $\mathrm{MR}=1+\mathrm{at}+\mathrm{bt}^{2}$ & Wang and Singh (1978) \\
\hline Diffusion approach & $M R=a \exp (-k t)+(1-a) \exp (-k b t)$ & Yaldýz and Ertekýn (2001) \\
\hline Mod. Henderson and Pabis & $M R=a \exp (-k t)+b \exp \left(-k_{0} t\right)+\operatorname{cexp}\left(-k_{1} t\right)$ & Karathanos (1999) \\
\hline \multicolumn{3}{|c|}{$\mathrm{MR}=$ moisture ratio $; \mathrm{a}, \mathrm{b}, \mathrm{c}=$ model constants, $\mathrm{k}, \mathrm{k}_{\mathrm{o}}, \mathrm{k}_{1}$ drying constants $\left(\mathrm{h}^{-1}\right)$ and $\mathrm{t}=$ drying time $(\mathrm{h})$} \\
\hline
\end{tabular}
solution due to osmotic pressure deficit between fruit and solution and solid gain (Equation 8) express the diffused solids $\left(\mathrm{kg}_{\text {solids gained }} / \mathrm{kg}_{\text {initial mass of fruit }}\right)$ from the osmotic solution into the fruit.

Air-drying of the osmotic dehydrated samples was

Table 1. Semi-empirical drying models 
carried out in an atmospheric drying oven (Heraeus T5028, Thermo Scientific, Austria) at $50^{\circ} \mathrm{C}$ for $15 \mathrm{hrs}$. Upon drying completion, dry matter was estimated gravimetrically using a vacuum oven (VD 53, Binder, Germany) at $70^{\circ} \mathrm{C}$ for $24 \mathrm{hrs}$ (AOAC, 1997). Based on the previous measurements the moisture content $\mathrm{MC}=$ $\left(\mathrm{M}_{\mathrm{t}}-\mathrm{m}_{\mathrm{f}}\right) / \mathrm{m}_{\mathrm{f}}$ and the moisture ratio $\mathrm{MR}=\mathrm{MC}_{\mathrm{t}} / \mathrm{MC}_{0}$ were estimated, where $\mathrm{m}_{\mathrm{f}}$ is the dry mass of the product $(\mathrm{kg}), \mathrm{M}_{\mathrm{t}}$ is the mass of the product at any time $(\mathrm{kg}), \mathrm{MC}_{\mathrm{o}}$ and $\mathrm{MC}_{\mathrm{t}}$ are the initial moisture content and the moisture content at any time respectively $\left(\mathrm{kg}_{\mathrm{w}} / \mathrm{kg}_{\mathrm{dm}}\right)$.

\subsection{Total soluble solids, acidity and ascorbic acid}

Measurement of the total soluble solids in the juice of the osmotic dehydrated and the air-dried fruits was carried out by a digital refractometer (SR-400, Japan) having $\pm 0.25^{\circ}$ Brix accuracy. The total soluble solids were expressed as $\mathrm{g}$ of solid per $100 \mathrm{~g}$ of juice (Brix). Measurement of the fruit's acidity in the juice of the osmotic dehydrated and air-dried fruits was carried out by a digital acidity meter (GMK-708, UK) having the accuracy of $\pm 0.05 \%$. Prior to the malic and citric acids measurement, dilution of $0.33 \mathrm{~mL}$ of juice into $20 \mathrm{~mL}$ of deionised water was carried out. The acidity was expressed in $\mathrm{g}$ of malic/citric acid per $100 \mathrm{~g}$ of juice.

The ascorbic acid was measured by an automatic titrator (HI902C, HANNA, USA) using a $0.02 \mathrm{~N}$ iodine buffer. For the measurement of the ascorbic acid, $15 \mathrm{~mL}$ of filtered fruit juice was diluted in a $250 \mathrm{~mL}$ beaker adding $100 \mathrm{~mL}$ of demineralised water, $8 \mathrm{~mL}$ of $16 \%$ sulphuric acid and $3 \mathrm{~g}$ of potassium iodide.

\subsection{Statistical analysis}

Analysis of variance (ANOVA) was carried out to identify significant effects of process parameters employing Statgraphics Centurion XVI (Statpoint Technologies, Virginia, USA) at significance level of $\mathrm{P} \leq 0.05$. Mean values were subjected to Fisher's Least Significant Difference test (LSD) at $\mathrm{P} \leq 0.05$. This statistical test is liberal with respect to the comparison wise error rate but is powerful to detect true differences. Nonlinear regression was carried out by the Statgraphics Centurion XVI (Statpoint Technologies, VA, USA) at significance level $\mathrm{P} \leq 0.05$ employing the LevenbergMarquardt optimisation algorithm (Mason et al., 2003).

\section{Results and discussion}

\subsection{Kinetics of water loss and solid gain}

In the osmotic process, two parameters are of great interest, water loss (Equation 7) and solid gain (Equation 8). In most of the cited studies the water loss curves (Figure 1a) exhibit initially a characteristic increase corresponding to high rate of water loss and solid gain followed by a falling rate at the later stages. The high water loss rate and solid gain at the initial stage of osmosis are due to higher osmotic driving forces between the fresh fruit and the surrounding hypertonic medium. The shape of the water loss curves during osmotic dehydration has been extensively reported (Panagiotou et al., 1999; Azoubel and Murr, 2004; Mundada et al., 2010; Ganjloo et al., 2012). Increasing the concentration of the osmotic solution increases the pressure deficit which leads to higher water loss and solid gain although not to the same extent. In most of the cited cases has been reported faster water loss than solid gain (Azoubel and Murr, 2004).
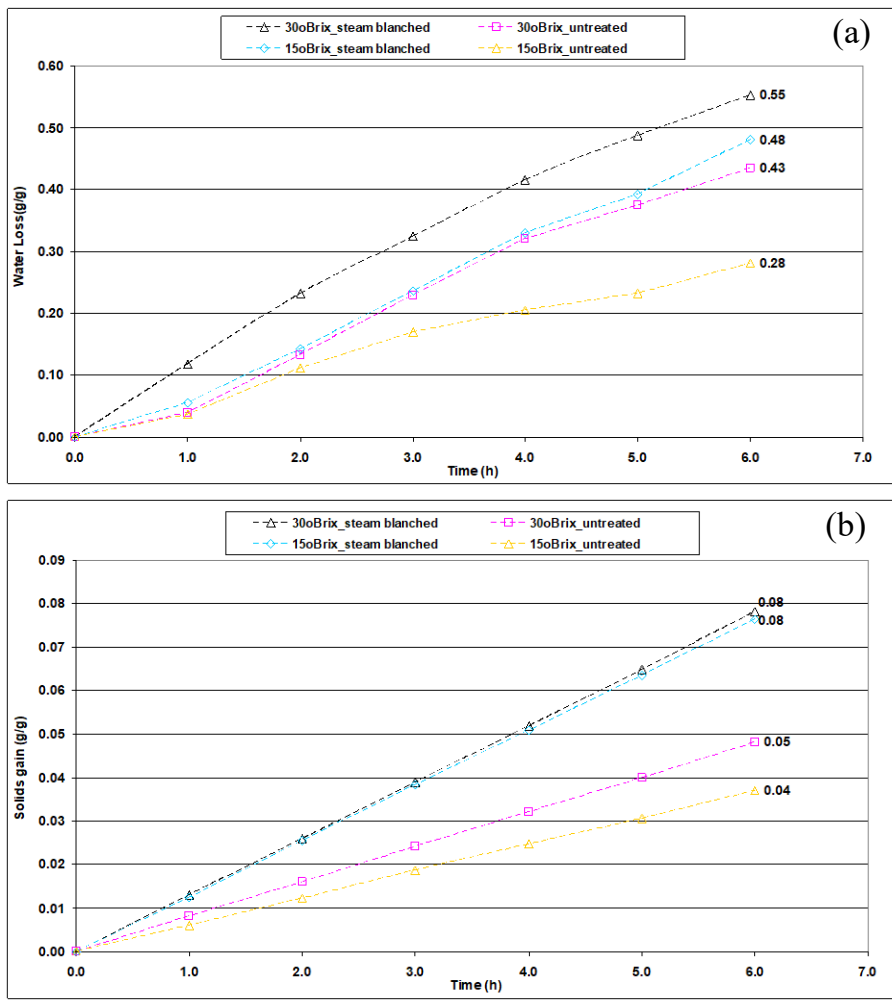

Figure 1. Water loss (a) and solid gain (b) of osmotic dehydrated sea buckthorn (var. Chuyskaya). Data points are the means of six replicates.

In Figure 1a is presented the water loss during the osmotic dehydration. It is observed that the steam blanched samples exhibited increased water loss, so their final values were $55 \%$ and $48 \%$ at $30^{\circ}$ Brix and $15^{\circ}$ Brix osmotic solutions respectively, compared to untreated samples that were $43 \%$ and $28 \%$ for the osmotic solutions of $30^{\circ} \mathrm{Brix}$ and $15^{\circ} \mathrm{Brix}$, respectively. This response can be attributed to disintegration of the waxy layer of the sea buckthorn epidermis taking place during steam blanching. The previous results are in agreement with those of Araya-Farias et al. (2014), who reported that steam blanching facilitates water loss during osmosis.

Panagiotou et al. (1999) evaluating the osmotic potential of glucose and sucrose reported that the former 
resulted in increased water loss compared to the latter, under the same osmotic solution concentration and treatment duration due to the higher osmotic effect of glucose compared to that of sucrose. The previous osmotic effect was attributed to sucrose's molecular weight $(342.3 \mathrm{~g} / \mathrm{mol})$ which is approximately twice that of glucose $(180.16 \mathrm{~g} / \mathrm{mol})$ and results in roughly halfmolecular concentration of sucrose solutions and consequently significantly lower osmotic pressure of the sucrose than the glucose solutions. Steviol glycoside molecular weight is $318.4 \mathrm{~g} / \mathrm{mol}$ which rank stevia to the same approximately osmotic potential of sucrose. From Figures 1a and b, it can be seen that solid gain is seven times smaller of water loss. This response can be attributed to the high molecular weight of steviol glycoside that favours water loss at the expense of solid gain as Mundada et al. (2010) explained. On the other hand, Hawkes and Flink (1978) reported that the progressive accumulation of solids during the osmotic dehydration, form a surface layer on the external cellular layer of sea buckthorn, which acts as a barrier against water loss and solid gain.

The Peleg model (Equation 1) was tested for its goodness of fitting water loss experimental data during the osmotic dehydration (Table 2). The fitting efficiency was very good in all the tested cases as this can be seen from the statistical estimates $\mathrm{R}_{\text {adj }}^{2}>99 \%$ and $\mathrm{SEE}<0.2$. The fitting efficiency can also be seen in Figure 2 as well as the effect of steam blanching on the final moisture ratio which after $6 \mathrm{~h}$ of osmotic dehydration was almost $50 \%$ less in the case of the steam blanched samples at $30^{\circ}$ Brix compared to those not be steamed blanched at $15^{\circ}$ Brix. The $K_{l}$ values for all the tested cases (pretreatment $\times$ solution concentration) are seen in Table 2 . The reciprocal of $K_{l}$ describes the initial mass transfer rate, e.g., the higher the $1 / K_{1}$ the higher the mass transfer rate. Based on the $1 / K_{1}$ values it is seen that as the osmotic solution concentration increases, increases the $1 /$ $K_{l}$ and therefore the initial mass transfer rate. The effect of steam blanching on the previous response is also obvious (cf. to Table 2) increasing the $1 / K_{1}$ value by $63 \%$ in the $15^{\circ}$ Brix solution and by $75 \%$ in the $30^{\circ}$ Brix solution. The $K_{2}$ value is related to equilibrium mass transfer terms, e.g., the higher the $1 / K_{2}$ value, the higher the equilibrium moisture content. The previous trend agrees with the respective variation of moisture content during the osmotic dehydration seen in Figure 2.

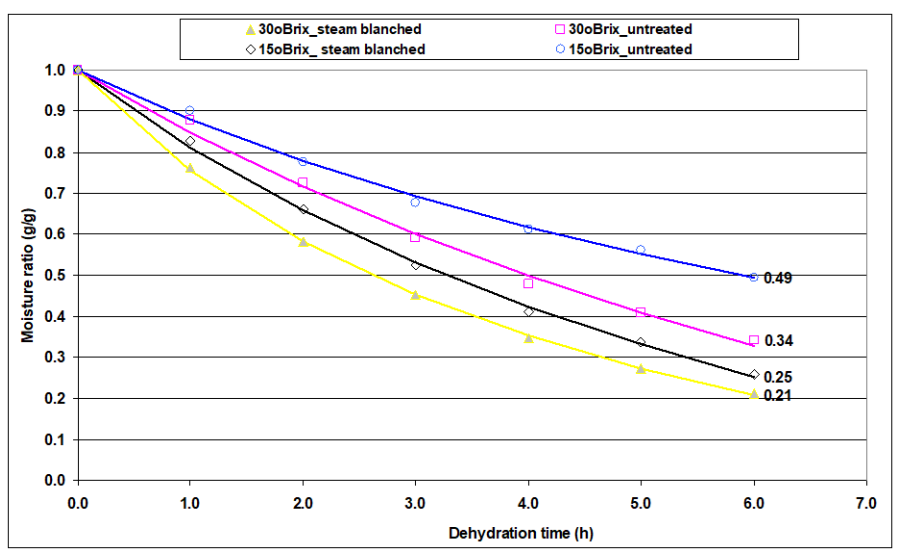

Figure 2. Experimental osmotic dehydration curves (points) of untreated and steam blanched sea buckthorn (var. Chuyskaya) with the simulated values (solid lines) from Peleg model (Equation 1). Data points are the means of six replicates.

The effective diffusivities of water loss and solid gain were estimated employing Fickian diffusion (Table 3 ). It is observed that diffusivity is increased as solute concentration increases from $15^{\circ} \mathrm{Brix}$ to $30^{\circ} \mathrm{Brix}$ as was expected. In the present study during the osmotic dehydration, the water diffusivities were ranged from 3.2 $-5.57 \times 10^{-11} \mathrm{~m}^{2} / \mathrm{s}$ for water loss and $1.27-2.03 \times 10^{-11} \mathrm{~m}^{2} / \mathrm{s}$ for solid gain at $30^{\circ}$ Brix and $2.12-4.27 \times 10^{-11} \mathrm{~m}^{2} / \mathrm{s}$ for water loss and $0.91-1.98 \times 10^{-11} \mathrm{~m}^{2} / \mathrm{s}$ for solid gain at $15^{\circ}$ Brix. Comparison of water diffusivity values found in literature should be carried out with great caution. Different experimental methods and conditions, mathematical analysis (analytical approach, method of slopes, regular regime method, numerical solution of water transport equations) and applied boundary conditions as well as different varieties of different physiological state and anatomy (peel, mesocarp, endocarp), should be taken into account otherwise the drawn conclusions could be misleading (Xanthopoulos et al., 2012). Park et al. (2002) working with pear cubes (case of no peel) found that water diffusivity was 0.35 $1.92 \times 10^{-9} \mathrm{~m}^{2} / \mathrm{s}$ for water loss and $0.20-3.60 \times 10^{-9} \mathrm{~m}^{2} / \mathrm{s}$ for solid gain at $40-60^{\circ} \mathrm{C}$. Lazarides et al. (1997) reported values $1.42-4.69 \times 10^{-10} \mathrm{~m}^{2} / \mathrm{s}$ for water diffusivity and 0.73 $-2.41 \times 10^{-10} \mathrm{~m}^{2} / \mathrm{s}$ for solid gain of apple slices (case of no peel) at $20-50^{\circ} \mathrm{C}$ and sucrose solution concentrations $45-$ $65^{\circ}$ Brix. Mundada et al. (2010) reported diffusivity for water loss and solid gain as $2.72-5.12 \times 10^{-10} \mathrm{~m}^{2} / \mathrm{s}$ and $1.47-5.15 \times 10^{-10} \mathrm{~m}^{2} / \mathrm{s}$ during osmotic dehydration of

Table 2. Peleg model parameters and goodness of fit for water loss during osmotic dehydration.

\begin{tabular}{cccccccc}
\hline & Treatment & $\mathrm{k}_{1}$ & $\mathrm{k}_{2}$ & $\mathrm{R}_{\text {adj }}{ }^{2}$ & $\mathrm{SEE}$ & $\begin{array}{c}1 / \mathrm{k}_{1} \\
\mathrm{~kg}_{\mathrm{w}} / \mathrm{kg}_{\mathrm{dm}} \mathrm{h}\end{array}$ & $\begin{array}{c}1 / \mathrm{k}_{2} \\
\mathrm{~kg}_{\mathrm{w}} / \mathrm{kg}_{\mathrm{db}}\end{array}$ \\
\hline \multirow{2}{*}{$30^{\circ}$ Brix } & $\mathrm{B}$ & 0.346 & 0.074 & 99.97 & 0.044 & 2.89 & 13.514 \\
& $\mathrm{NB}$ & 0.606 & 0.055 & 99.46 & 0.182 & 1.65 & 18.182 \\
\multirow{2}{*}{$15^{\circ}$ Brix } & $\mathrm{B}$ & 0.486 & 0.071 & 99.85 & 0.101 & 2.058 & 14.085 \\
& $\mathrm{NB}$ & 0.794 & 0.046 & 99.52 & 0.121 & 1.261 & 21.739 \\
\hline
\end{tabular}

$\mathrm{B}=$ steam blanched; $\mathrm{NB}=$ no steam blanched 
pomegranate arils in sucrose solution at $35-55^{\circ} \mathrm{C}$ and $40-$ $60^{\circ}$ Brix. Panades et al. (2008) reported water diffusivity $0.69-1.47 \times 10^{-10} \mathrm{~m}^{2} / \mathrm{s}$ during osmotic dehydration of guava (case of no peel) in sucrose solution. Khoyi and Hesari (2007) reported diffusivity $1.06-4.06 \times 10^{-9} \mathrm{~m}^{2} / \mathrm{s}$ of water loss and $7.69-3.13 \times 10^{-9} \mathrm{~m}^{2} / \mathrm{s}$ for solid gain of apricot slices (case of no peel) in sucrose solution.

Table 3. Diffusivity for water loss and solid gain during the osmotic dehydration and air-drying of sea buckthorn (var. Chuyskaya).

\begin{tabular}{|c|c|c|c|c|}
\hline & & \multicolumn{2}{|c|}{ Osmotic dehydration } & \multirow{2}{*}{ Air-drying } \\
\hline & & Water loss & Solid gain & \\
\hline & Treatment & $\begin{array}{c}\left.\mathrm{D}_{\mathrm{WL}}\right|_{\text {avg }} \\
\mathrm{m}^{2} / \mathrm{s} \\
\end{array}$ & $\begin{array}{c}\left.\mathrm{D}_{\mathrm{SG}}\right|_{\text {avg }} \\
\mathrm{m}^{2} / \mathrm{s}\end{array}$ & $\begin{array}{l}\mathrm{D}_{\text {eff }} \\
\mathrm{m}^{2} / \mathrm{s} \\
\end{array}$ \\
\hline \multirow{2}{*}{$30^{\circ}$ Brix } & B & $5.57 \times 10^{-11}$ & $2.03 \times 10^{-11}$ & $2.29 \times 10^{-11}$ \\
\hline & NB & $3.20 \times 10^{-11}$ & $1.27 \times 10^{-11}$ & $1.66 \times 10^{-11}$ \\
\hline \multirow{2}{*}{$15^{\circ}$ Brix } & B & $4.27 \times 10^{-11}$ & $1.98 \times 10^{-11}$ & $2.11 \times 10^{-11}$ \\
\hline & NB & $2.12 \times 10^{-11}$ & $0.91 \times 10^{-11}$ & $1.56 \times 10^{-11}$ \\
\hline
\end{tabular}

$\mathrm{B}=$ steam blanched $\mathrm{NB}=$ no steam blanched

\subsection{Ascorbic acid}

The analysis of variance (Table 4) showed that only steam blanching (treatment) affected significantly the ascorbic acid concentration $(\mathrm{P}<0.05)$. The previous response is expected since ascorbic acid is thermal sensitive and highly unsaturated, making it susceptible to degradation due to oxidation and heat treatment. The ascorbic acid concentration in Table 5 is higher than the one reported from Beveridge et al. (2002) and ArayaFarias et al. (2011) for the Indian Summer cultivar which was $175 \mathrm{mg} / 100 \mathrm{~g}$ and $184 \mathrm{mg} / 100 \mathrm{~g}$ respectively. Zeb (2004) reported that the variation of ascorbic acid in sea buckthorn depends on whether is measured on the seeds $(64.4-92.7 \mathrm{mg} / 100 \mathrm{~g}$ of seed), juice $(216 \mathrm{mg} / 100 \mathrm{~g}$ of berries) or pulp upon juice and pulp removal (481 $\mathrm{mg} / 100 \mathrm{~g}$ of berries). Variations among most nutrients within origin or between origins offer prospects for future study. The high variability in sea buckthorn composition found in literature depends on the variety, maturity and growing location (Beveridge et al., 1999). As it is seen in Table 5, the steam blanched samples exhibit a higher reduction of the initial ascorbic acid (control) compared to untreated samples. In particular, the steam blanched samples exhibited $52 \%$ and $71 \%$ reduction of the initial ascorbic acid at $15^{\circ}$ Brix and $30^{\circ}$ Brix stevia solutions respectively (Table 5). Santos and Silva (2008) reported increased ascorbic acid losses, even $50 \%$, along with increased water losses for different osmotic solutions due to steam blanching application that caused cracks on the waxy layer of fruit epidermis. On the other hand, the untreated samples exhibited less ascorbic acid losses of $23 \%$ and $28 \%$ respectively in the stevia solutions of $30^{\circ}$ Brix and $15^{\circ}$ Brix. Santos and Silva (2008) attributed the increased retention of ascorbic acid in the final product, at the formation of a coherent layer of sugars on their epidermis acting as a barrier to water transport and ascorbic acid loss.

Table 4. ANOVA of the factors and their interactions affecting the ascorbic acid of sea buckthorn (var. Chuyskaya) per stevia solution and treatment.

\begin{tabular}{lccc}
\hline \multicolumn{1}{c}{ Source } & df & F-Ratio & P-Value \\
\hline Main effects & & & \\
A: Stevia solution & 1 & 0.65 & $0.435^{\mathrm{NS}}$ \\
B: Treatment & 4 & 43.88 & $0.000^{*}$ \\
Interactions & & & \\
$\mathrm{A} \times \mathrm{B}$ & 4 & 3.12 & $0.056^{\mathrm{NS}}$ \\
Residual & 12 & & \\
\hline Total & 21 & & \\
\hline
\end{tabular}

$\mathrm{NS}=$ not significant; $*=$ significant at $\mathrm{P} \leq 0.05 ; \mathrm{df}=$ degree of freedom

Table 5. Average ascorbic acid of the osmotic dehydrated sea buckthorn (var. Chuyskaya) per stevia aqueous solution and treatment. Values in the parenthesis are the ascorbic acid loss.

\begin{tabular}{cccc}
\multicolumn{2}{c}{ Treatment } & \multicolumn{2}{c}{ Ascorbic acid $(\mathrm{mg} / \mathrm{L})$} \\
\cline { 2 - 4 } & & \multicolumn{1}{c}{$15^{\circ}$ Brix } & $30^{\circ}$ Brix \\
\hline Control & 5 & 495.03 & 495.03 \\
OD.B. & 1 & $238.5(52 \%)$ & $145.2(71 \%)$ \\
OD.NB. & 2 & $354.4(28 \%)$ & $379.2(23 \%)$ \\
OD.B.D. & 3 & $26.4(95 \%)$ & $44.0(91 \%)$ \\
OD.NB.D. & 4 & $96.5(80 \%)$ & $173.7(65 \%)$ \\
\hline
\end{tabular}

OD.B $=$ osmotic dehydrated and steam blanched; OD.NB = osmotic dehydrated with no steam blanched; OD.B.D = osmotic dehydrated, steam blanched and dried; OD.NB.D = osmotic dehydrated with no steam blanched and dried.

Upon osmotic dehydration, the samples were airdried; the steam blanched samples at the end of the air drying had higher ascorbic acid losses of $95 \%$ and $91 \%$ for the $15^{\circ}$ Brix and $30^{\circ}$ Brix osmotic solutions respectively, while the untreated samples exhibited ascorbic acid losses of $80 \%$ and $65 \%$ respectively. As was expected, osmotic dehydration and air-drying involve thermal treatments and as such, causes a significant reduction of the ascorbic acid since it is thermally sensitive making it susceptible to degradation due to oxidation and heat processing. The previous results are consistent with those of Santos and Silva (2008) and Araya-Farias et al. (2011) who reported that the preservation of the nutrients in the sea buckthorn, especially that of the ascorbic acid depends on the temperature-time integral as well as the final moisture content of the produce.

\subsection{Total soluble solids and acidity}

The analysis of variance (Table 6) showed that the 
Table 6. ANOVA of the factors and their interactions affecting the total soluble solids, citric and malic acidity of sea buckthorn (var. Chuyskaya) per stevia solution and treatment.

\begin{tabular}{|c|c|c|c|c|c|c|c|}
\hline \multirow[b]{2}{*}{ Source } & \multirow[b]{2}{*}{$\mathrm{df}$} & \multicolumn{2}{|c|}{ TTS } & \multicolumn{2}{|c|}{ Citric acid } & \multicolumn{2}{|c|}{ Malic acid } \\
\hline & & F-Ratio & P-Value & F-Ratio & P-Value & F-Ratio & P-Value \\
\hline \multicolumn{8}{|l|}{ Main effects } \\
\hline A: Stevia solution & 1 & 1.97 & $0.176^{\mathrm{NS}}$ & 0.08 & $0.775^{\mathrm{NS}}$ & 0.58 & $0.457^{\mathrm{NS}}$ \\
\hline B: Treatment & 4 & 18.84 & $0.000 *$ & 24.97 & $0.000 *$ & 4.12 & $0.013 *$ \\
\hline \multicolumn{8}{|l|}{ Interactions } \\
\hline $\mathrm{A} \times \mathrm{B}$ & 4 & 2.44 & $0.081^{\mathrm{NS}}$ & 18.11 & $0.000^{*}$ & 7.19 & $0.0009^{*}$ \\
\hline Residual & 20 & & & & & & \\
\hline Total & 29 & & & & & & \\
\hline
\end{tabular}

total soluble solids were significantly affected by steam blanching $(\mathrm{P}<0.05)$. The four experimental series, regarding the total soluble solids, were differed significantly among them as well as with the control samples. It was observed that the total soluble solids increase during the osmotic dehydration was higher in steam blanched samples against those not to, compared to the control samples (Table 7). This response is expected since steam blanching disintegrates the waxy layer of fruits epidermis causing cracks, facilitating likewise the influx of the osmotic solution into the mesocarp. This observation is in line with Araya-Farias et al. (2011) findings according to whose, steam blanching increases drastically total soluble solids in osmotically dehydrated sea buckthorn. A difference in the total soluble solids upon air-drying completion was also observed, as air-drying of the steam blanched samples resulted in higher total soluble solids compared to samples that had not been steam blanched (Table 7).

Table 7. Total soluble solids and dry matter of the osmotic dehydrated sea buckthorn (var. Chuyskaya) per stevia aqueous solution and treatment. Values in the parenthesis are the dry matter increase.

\begin{tabular}{lcccc}
\hline \multirow{2}{*}{ Treatment } & \multicolumn{2}{c}{$30^{\circ}$ Brix } & \multicolumn{2}{c}{$15^{\circ}$ Brix } \\
\cline { 2 - 5 } & ${ }^{\circ}$ Brix & $\begin{array}{c}\text { Dry matter } \\
\mathrm{g}\end{array}$ & ${ }^{\circ}$ Brix & $\begin{array}{c}\text { Dry matter } \\
\mathrm{g}\end{array}$ \\
\hline Control & 8.9 & 2.32 & 8.9 & 2.32 \\
OD.B. & 12.75 & - & 10.5 & - \\
OD.NB. & 11.55 & - & 9.5 & - \\
OD.B.D. & 12.27 & $4.28(84 \%)$ & 11.73 & $4.23(82 \%)$ \\
OD.NB.D. & 7.53 & $3.56(53 \%)$ & 7.17 & $3.23(39 \%)$ \\
\hline
\end{tabular}

OD.B = osmotic dehydrated and steam blanched; OD.NB = osmotic dehydrated with no steam blanched; OD.B.D = osmotic dehydrated, steam blanched and dried; OD.NB.D = osmotic dehydrated with no steam blanched and dried.

In addition, it was observed that the dry matter increase (Table 7) during the osmotic dehydration (Equation 3) was significantly affected by the steam blanching application. In particular, the samples that had been steam blanched and then osmotic dehydrated in $30^{\circ}$ Brix solution, exhibited an increase of $84 \%$ in the dry matter while the samples that had not been steam blanched an increase of $53 \%$. Similarly, the samples osmotically dehydrated in $15^{\circ}$ Brix solution exhibited $82 \%$ dry matter increase when steam blanching had been preceded, and only $39 \%$ when the samples had not steam blanched. The effect of stevia solutions was not so pronounced in the steam blanched samples as far as the total soluble solids and the dry matter concerns (Table 7) probably due to accumulation of solids on the external cellular layer that acts as a barrier against the uptake of solids as has been previously explained.

Table 8. Average acidity of the osmotic dehydrated sea buckthorn (var. Chuyskaya) per stevia solution and treatment.

\begin{tabular}{lcccc}
\hline \multirow{2}{*}{ Treatment } & \multicolumn{2}{c}{$30^{\circ}$ Brix } & \multicolumn{2}{c}{$15^{\circ}$ Brix } \\
\cline { 2 - 5 } & $\begin{array}{c}\text { Citric acid } \\
\mathrm{mg} / \mathrm{L}\end{array}$ & $\begin{array}{c}\text { Malic acid } \\
\mathrm{mg} / \mathrm{L}\end{array}$ & $\begin{array}{c}\text { Citric acid } \\
\mathrm{mg} / \mathrm{L}\end{array}$ & $\begin{array}{c}\text { Malic acid } \\
\mathrm{mg} / \mathrm{L}\end{array}$ \\
\hline Control & 0.53 & 0.43 & 0.53 & 0.43 \\
OD.B. & 0.47 & 0.29 & 0.45 & 0.25 \\
OD.NB. & 0.41 & 0.22 & 0.41 & 0.21 \\
OD.B.D. & 0.32 & 0.15 & 0.38 & 0.18 \\
OD.NB.D. & 0.38 & 0.19 & 0.24 & 0.13 \\
\hline
\end{tabular}

OD.B = osmotic dehydrated and steam blanched; OD.NB = osmotic dehydrated with no steam blanched; OD.B.D = osmotic dehydrated, steam blanched and dried; OD.NB.D = osmotic dehydrated with no steam blanched and dried.

Beveridge et al. (2002) reported that quantitatively the most important organic acid in sea buckthorn is malic acid, but smaller quantities of citric, tartaric, and succinic acid exists, contributing to total titratable acidity. The acid values reported in the literature, range 1.11-2.34 $\mathrm{mg} / 100 \mathrm{~g}$ for malic acid and $0.042-0.234 \mathrm{mg} / 100 \mathrm{~g}$ for citric acid depending on the variety, maturity and growing location (Beveridge et al., 1999). In the present study, the tested variety of sea buckthorn exhibited higher citric acid concentration as can be seen in Table 8 . The analysis of variance (Table 6) showed that the acidity regarding the citric and malic acids was significantly affected by the interaction of steam blanching with the stevia solution concentration $(\mathrm{P}<0.05)$. From Table 8 , it is seen that the malic and 
citric acid concentrations tend to decrease during the osmotic dehydration and the following air-drying, reaching in some cases even $60-70 \%$ reduction compared to control samples.

\subsection{Drying kinetics during hot-air drying}

The initial moisture content of the samples subjected to osmotic dehydration and air-drying, was ranged between $1.93-2.28 \mathrm{~kg}_{\mathrm{w}} / \mathrm{kg}_{\mathrm{dm}}$ in the case of $30^{\circ}$ Brix (steam blanched) and $2.28-2.88 \mathrm{~kg}_{\mathrm{w}} / \mathrm{kg}_{\mathrm{dm}}$ in the case of $15^{\circ}$ Brix (steam blanched). Respectively, the initial moisture content of the untreated samples was ranged between 1.73-2.42 $\mathrm{kg}_{\mathrm{w}} / \mathrm{kg}_{\mathrm{dm}}$ in the case of $30^{\circ}$ Brix and $2.28-2.50 \mathrm{~kg}_{\mathrm{w}} / \mathrm{kg}_{\mathrm{dm}}$ in the case of $15^{\circ}$ Brix. In Figure 3 are seen the experimental drying curves of sea buckthorn at $50^{\circ} \mathrm{C}$ along with the predicted moisture content curves by the Logarithmic model (Table 1). The moisture content decreases exponentially with drying time and thus, drying appears to take place at the falling rate period. The coefficients of Logarithmic model calculated from the non-linear regression are presented in Table 9. As can be seen, the Logarithmic model describes efficiently the experimental drying curves based on the statistical estimates $\mathrm{R}_{\text {adj }}^{2}>99 \%$ and $\mathrm{SEE} \leq 0.025$. In Figure 3 is observed that the steam blanched samples in both osmotic solutions were dried faster, approximately 4-5 hours shorter than the untreated samples (16-17 hrs), a fact that comes as a consequence of weakening of the waxy layer lying on fruit's peel due to steam blanching.

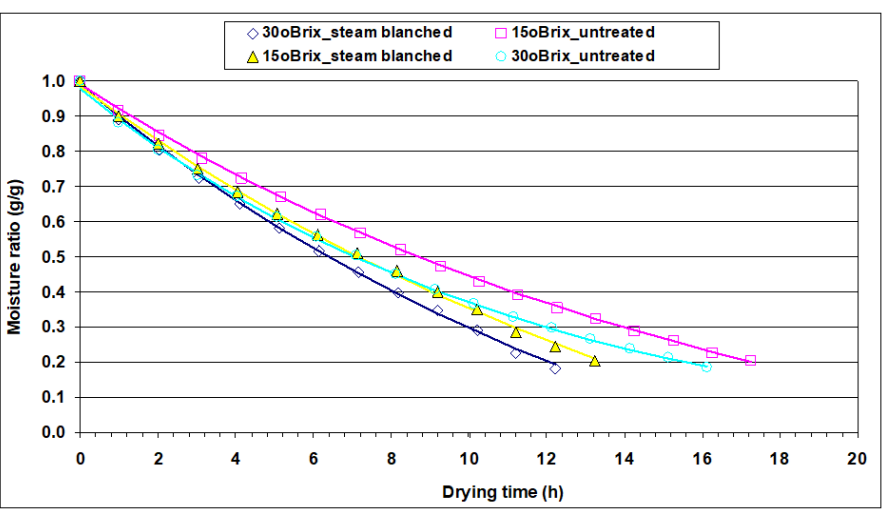

Figure 3. Experimental air-drying curves (points) of untreated and steam blanched sea buckthorn (var. Chuyskaya) with the simulated values (solid lines) from the Logarithmic model, $\mathrm{MR}_{\mathrm{f}}=0.2$ (cf. to Table 1). Data points are the means of three replicates.
Figure 4 presents the water diffusivity against the moisture content for all the experimental series during the air-drying. It is noted that the water diffusivity of the steam blanched samples lie above the untreated ones and in particular the water diffusivity of steam blanched samples range between $2.11-2.29 \times 10^{-11} \mathrm{~m}^{2} / \mathrm{s}$ while those of untreated samples between $1.56-1.66 \times 10^{-11} \mathrm{~m}^{2} / \mathrm{s}$. Kyriakopoulou et al. (2013) attributed this response to thermal pre-treatment that reduced the resistance of water diffusion through product's epidermis, in the present case, reducing the waxy layer lies on sea buckthorn epidermis. Since estimation of the water diffusivity was carried out at the same drying temperature $\left(50^{\circ} \mathrm{C}\right)$, its apparent sharp rise as the moisture ratio decreases in the drying curves, is driven solely by the moisture content. Saravacos and Maroulis (2001) reported that water diffusivity increases as moisture content decreases in porous foods due to porosity formation, which facilitates water transport within the drying product. At very low moisture contents $(\mathrm{MR}<0.1)$ the strongly bound water in food matrix forces water diffusivity to be reduced sharply.

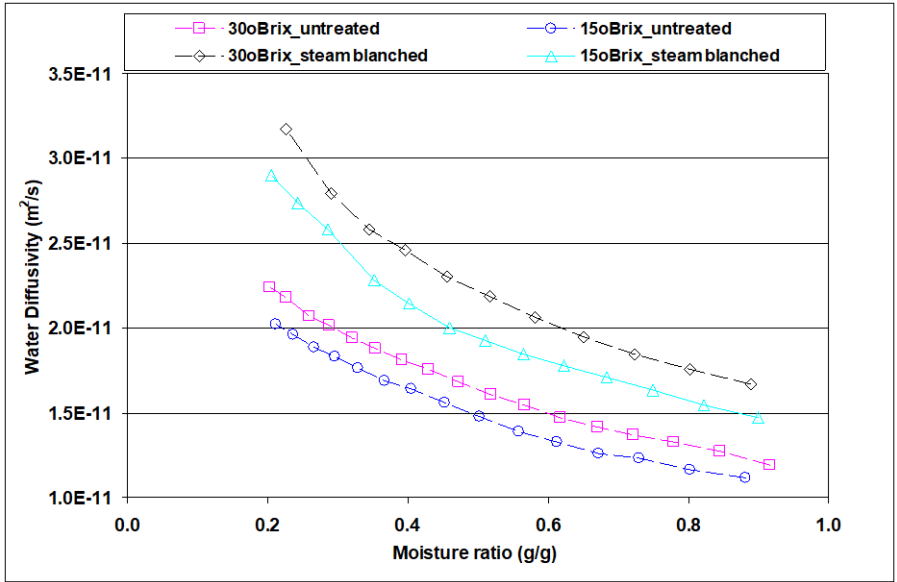

Figure 4. Water diffusivity of sea buckthorn (var. Chuyskaya) vs moisture ratio (dimensionless) for all the experimental series $\left(\mathrm{MR}_{\mathrm{f}}=0.2\right)$. Data points are the means of three replicates.

\section{Conclusion}

Solution concentration and steam blanching pretreatment had a significant effect on the solid gain and water loss during the osmotic dehydration of sea buckthorn while both increased with increasing solution concentration but not to the same extent. In particular, solid gain was seven times lesser compared to water loss

Table 9. Coefficients of Logarithmic model (cf. to Table 1) per experimental series.

\begin{tabular}{ccccccc}
\hline & Treatment & $\mathrm{a}$ & $\mathrm{b}$ & $\mathrm{c}$ & $\mathrm{R}_{\text {adj }}^{2}$ & $\mathrm{SEE}$ \\
\hline \multirow{2}{*}{$30^{\circ}$ Brix } & $\mathrm{B}$ & 3.43 & $5.75 \times 10^{-2}$ & -1.29 & 99.89 & 0.019 \\
& $\mathrm{NB}$ & 2.64 & $5.78 \times 10^{-2}$ & -0.54 & 99.96 & 0.009 \\
\multirow{2}{*}{$15^{\circ}$ Brix } & $\mathrm{B}$ & 4.17 & $4.96 \times 10^{-2}$ & -1.63 & 99.87 & 0.025 \\
& $\mathrm{NB}$ & 2.52 & $8.42 \times 10^{-2}$ & -0.2 & 99.85 & 0.024 \\
\hline
\end{tabular}

$\mathrm{B}=$ steam blanched; $\mathrm{NB}=$ no steam blanched 
fact that was attributed to the high molecular weight of steviol glycoside which favours water loss at the expense of solid gain. Peleg model described efficiently the mass transfer kinetics at the studied experimental cases based on the statistical estimates $\mathrm{R}_{\text {adj }}^{2}>99 \%$ and $\mathrm{SEE} \leq 0.18$. Steam blanching caused significant reduction of the ascorbic acid concentration and facilitated the total soluble solids and dry matter gain, reaching up to $84 \%$. The Logarithmic model found to describe efficiently the experimental drying curves based on the statistical estimates $\mathrm{R}_{\text {adj }}^{2}>99 \%$ and $\mathrm{SEE} \leq 0.025$. The water diffusivity in steam blanched samples was higher than in the untreated ones and in particular the water diffusivity of steam blanched samples ranged between 2.11-2.29 $\times 10$ ${ }^{-11} \mathrm{~m}^{2} / \mathrm{s}$ while those of untreated samples between 1.56 $1.66 \times 10^{-11} \mathrm{~m}^{2} / \mathrm{s}$.

\section{Acknowledgments}

We would like to thank Ms Olga Georgiadou and Ms Ina Themeli for conducting the experiments. $\mathrm{Mr}$ Charalampos Templalexis gratefully acknowledge financial support from Bodossaki Foundation for financial support during his post-graduate studies.

\section{References}

Abou-Arab, A.E., Abou-Arab, A.A. and Abu-Salem, M.F. (2010). Physico-Chemical Assessment of Natural Sweeteners Steviosides Produced from Stevia Rebaudiana Bertoni Plant. African Journal of Food Science, 4(5), 269-281.

AOAC, 1997. Official Methods of Analysis. $16^{\text {th }}$ ed. Washington, DC: Association of Official Analytical Chemists.

Araya-Farias, M., Macaigne, O. and Ratti, C. (2014). On the Development of Osmotically Dehydrated Sea Buckthorn Fruits: Pre-Treatments, Osmotic Dehydration, Post Drying Techniques, and Nutritional Quality. Drying Technology, 32(7), 813819. https://doi.org/10.1080/07373937.2013.866143

Araya-Farias, M., Makhlouf, J. and Ratti, C. (2011). Drying of Sea Buckthorn (Hippophae Rhamnoides L.) Berry: Impact of Dehydration Methods on Kinetics and Quality. Drying Technology, 29(3), 351 -359. https://doi.org/10.1080/07373937.2010.497590

Azoubel, P.M. and Murr, F.E.X. (2004). Mass Transfer Kinetics of Osmotic Dehydration of Cherry Tomato. Journal of Food Engineering, 61, 291-295. https:// doi.org/10.1016/S0260-8774(03)00132-8

Bal, L.M., Meda, V., Naik, S.N. and Satya, S. (2011). Sea Buckthorn Berries: A Potential Source of Valuable Nutrients for Nutraceuticals and Cosmeceuticals. Food Research International, 44,
$1718-1727$.

https://doi.org/10.1016/

j.foodres.2011.03.002

Beveridge, T., Li, T. S., Oomah, B.D. and Smith, A. (1999). Sea buckthorn products: manufacture and composition. Journal of Agricultural and Food Chemistry, 47(9), 3480-3488. https:// doi.org/10.1021/jf981331m

Beveridge, T., Harrison, E. and Drover, J. (2002). Processing Effects on the Composition of Sea Buckthorn Juice from Hippophae Rhamnoides L. cv. Indian Summer. Journal of Agricultural and Food Chemistry, 50, 113-116. https://doi.org/10.1021/ jf010369n

Crank, J. (1975). Mathematics of Diffusion. $2^{\text {nd }}$ ed. Oxford University Press: London.

Diamente, L.M. and Munro, P.A. (1993). Mathematical Modelling of the Thin Layer Solar Drying of Sweet Potato Slices. Solar Energy, 51(4), 271-276. https:// doi.org/10.1016/0038-092X(93)90122-5

Efremov, G. and Kudra, T. (2005). Model-Based Estimate for Time-Dependent Apparent Diffusivity. Drying Technology, 23(12), 2513-2522. https:// doi.org/10.1080/07373930500340387

Ganjloo, A., Rahman, R.A., Bakar, J., Osman, A. and Bomakr, M. (2012). Kinetics Modelling of Mass Transfer Using Peleg's Equation during Osmotic Dehydration of Seedless Guava (Psidium Guajava L.): Effect of Process Parameters. Food Bioprocess Technology, 5, 2151. https://doi.org/10.1007/s11947011-0546-2

Hawkes, J. and Flink, J.M. (1978). Osmotic Concentration of Fruit Slices Prior to Freeze Dehydration. Journal of Food Processing and Preservation, 2(4), 265-284. https://doi.org/10.1111/ j.1745-4549.1978.tb00562.x

Henderson, S.M. (1974). Progress in Developing the Thin Layer Drying Equation. Transaction of the ASAE, 17(6), 1167-1172. https:// doi.org/10.13031/2013.37052)@1974

Karathanos, V.T. (1999). Determination of Water Content of Dried Fruits by Drying Kinetics. Journal of Food Engineering, 39(4), 337-344. https:// doi.org/10.1016/S0260-8774(98)00132-0

Khoyi, M.R. and Hesari, J. (2007). Osmotic Dehydration of Apricot in Sucrose Solution. Journal of Food Engineering, 78(4), 1355-60. https:// doi.org/10.1016/j.jfoodeng.2006.01.007

Kyriakopoulou, K., Pappa, A., Krokida, M., Detsi, A. and Kefalas, P. (2013). Effects of Drying and Extraction Methods on the Quality and Antioxidant Activity of Sea Buckthorn (Hippophae Rhamnoides) Berries and Leaves. Drying Technology, 31(9), 1063 
-1076 .

doi.org/10.1080/07373937.2013.773907

https://

Lazarides, H.N., Gekas, V. and Mavroudis, N. (1997). Apparent Mass Diffusivities in Fruit and Vegetable Tissues Undergoing Osmotic Processing. Journal of Food Engineering, 31(3), 315-324. https:// doi.org/10.1016/S0260-8774(96)00084-2

Lemus-Mondaca, R., Vega-Gálvez, A., Zura-Bravo, L. and Ah-Hen, K. (2012). Stevia Rebaudiana Bertoni, Source of a High-Potency Natural Sweetener: A Comprehensive Review on the Biochemical, Nutritional and Functional Aspects. Food Chemistry, 132(3), 1121-1132. https://doi.org/10.1016/ j.foodchem.2011.11.140

Lentzou, D., Boudouvis, A.G., Karathanos, V. and Xanthopoulos, G. (2019). A Moving Boundary Model for Fruit Isothermal Drying and Shrinkage: An Optimisation Method for Water Diffusivity and Peel Resistance Estimation. Journal of Food Engineering, 263, 299-310. https://doi.org/10.1016/ j.jfoodeng.2019.07.010

Mason, R.L., Gunst, R.F. and Hess, J.L. (2003). Statistical Design and Analysis of Experiments: With Applications to Engineering and Science, $2^{\text {nd }}$ ed. New York: Wiley-Interscience.

Mundada, M., Hathan, B.S. and Maske, S. (2010). Mass Transfer Kinetics during Osmotic Dehydration of Pomengranate Arils. Journal of Food Science, 76(1), E31-E39. https://doi.org/10.1111/j.17503841.2010.01921.x

Pakowski, Z. and Mujumdar, A.S. (2006). Basic Process Calculations and Simulations in Drying. In Mujumdar, A.S. (Ed.). Handbook of Industrial Drying. $3^{\text {rd }}$ ed., p. 54-78. Boca Raton, Florida: Taylor and Francis Group LLC.

Panades, G., Castro, D., Chiralt, A., Fito, P., Nunez, M. and Jimenez, R. (2008). Mass Transfer Mechanism Occurring during Osmotic Dehydration of Guava. Journal of Food Engineering, 87(3), 386-390. https://doi.org/10.1016/j.jfoodeng.2007.12.021

Panagiotou, N.M., Karathanos, V.T. and Maroulis, Z.B. (1999). Effect of Osmotic Agent on Osmotic Dehydration of Fruits. Drying Technology, 17(1/2), 175-189.

doi.org/10.1080/07373939908917524

Park, K.J., Bin, A., Brod, F.P.R. and Park, T.H.K.B. (2002). Osmotic Dehydration Kinetics of Pear D' Anjou (Pyrus Communis L.). Journal of Food Engineering, 52, 293-298. https://doi.org/10.1016/ S0260-8774(01)00118-2

Peleg, M. (1988). An Empirical Model for the Description of Moisture Sorption Curves. Journal of
Food Science, 53(4), 1216-1227. https:// doi.org/10.1111/j.1365-2621.1988.tb13565.x

Santos, P.H.S. and Silva, M.A. (2008). Retention of Ascorbic Acid in Drying Processes of Fruits and Vegetables-A Review. Drying Technology, 26(12), 1421-1437. doi.org/10.1080/07373930802458911

https://

Saravacos, G.D. and Maroulis, Z.B. (2001). Transport Properties of Foods. $1^{\text {st }}$ ed., p. 163-236. New York: Marcel Decker Inc.

Savita, S.M., Sheela, K., Sunanda, S., Shankar, A.G. and Ramakrishna, P. (2004). Stevia rebaudiana-A Functional Component for Food Industry. Journal of Human Ecology, 15(4), 261-264. https:// doi.org/10.1080/09709274.2004.11905703

Sharaf-Eldeen, Y.I., Blaisdell, J.L. and Hamdy, M.Y. (1980). A Model for Ear Corn Drying. Transactions of ASAE., 23, 1261-1271. https:// doi.org/10.13031/2013.34757)@1980

Wang, C.Y. and Singh, R.P. (1978). A Single Layer Drying Equation for the Rough Rice. ASAE paper no. 3001 .

Whith, G.M., Bridges, T.C., Loewer, O.J. and Ross, I.J. (1978). Seed Coat Damage in Thin Layer Drying of Soybeans as Affected by Drying Conditions. ASAE paper no. $3052 . \quad \mathrm{https} / /$ doi.org/10.13031/2013.34559)@1980

Xanthopoulos, G., Lambrinos, Gr. and Manolopoulou, H. (2007). Evaluation of Thin Layer Models for Mushroom (Agaricus bisporus) Drying. Drying Technology 25(9), 1471-1481. https:// doi.org/10.1080/07373930701537179

Xanthopoulos, G., Oikonomou, N. and Lambrinos, Gr. (2007). Applicability of a Single Layer Drying Model to Predict the Drying Rate of Whole Figs. Journal of Food Engineering, 81(3), 553-559. https://doi.org/10.1016/j.jfoodeng.2006.11.033

Xanthopoulos, G., Yanniotis, S. and Lambrinos, Gr. (2010). Study of the Drying Behaviour in Peeled and Unpeeled Whole Figs. Journal of Food Engineering, 97(3), 419-424. https://doi.org/10.1016/ j.jfoodeng.2009.10.037

Xanthopoulos, G., Yanniotis, S. and Talaiporou, E. (2012). Influence of Salting on Drying Kinetics and Diffusivity of Tomato Halves. International Journal of Food Properties, 15(4), 847-863. https:// doi.org/10.1080/10942912.2010.506018

Yadav, A.K. and Singh, S.V. (2014). Osmotic Dehydration of Fruits and Vegetables: A Review. Journal of Food Science and Technology, 51(9), 1654-1673. https://doi.org/10.1007/s13197-012-0659 $-2$ 
Yağcioğlu, A., Değirmencioğlu, A. and Çağatay, F. (1999). Drying Characteristics of Laurel Leaves under Different Drying Conditions presented at the Proceedings of the $7^{\text {th }}$ International Congress on Agricultural Mechanization and Energy, p. 565-569. Adana, Turkey: Faculty of Agriculture, Cukurova University.

Yaldýz, O. and Ertekýn, C. (2001). Thin Layer Solar Drying of Some Vegetables. Drying Technology, 19 (3-4), 583-596. https://doi.org/10.1081/DRT100103936

Zeb, A. (2004). Chemical and Nutritional Constituents of Sea Buckthorn Juice. Pakistan Journal of Nutrition, 3(2), 99-106.

Zhang, Q. and Litchfield, J.B. (1991). An optimization of intermittent corn drying in a laboratory scale thin layer dryer. Drying Technology, 9(2), 383-395. https://doi.org/10.1080/07373939108916672 